\title{
Immunostimulating influence of herbal biomedicines on nonspecific immunity in Grouper Epinephelus tauvina juvenile against Vibrio harveyi infection
}

\author{
S. M. J. Punitha - M. M. Babu - V. Sivaram - V. S. Shankar - S. A. Dhas • \\ T. C. Mahesh · G. Immanuel · T. Citarasu
}

Received: 5 July 2007/ Accepted: 28 December 2007/Published online: 19 January 2008

(C) The Author(s) 2008

\begin{abstract}
Herbals such as Cynodon dactylon, Piper longum, Phyllanthus niruri, Tridax procumbens, and Zingiber officinalis were extracted with acetone, benzene, butanol, and petroleum ether and screened against the pathogen Vibrio harveyi isolated from the infected Grouper Epinephalus tauvina. Among the different solvent extractions screening to $V$. harveyi, petroleum ether extracts were suppressed significantly $(P<0.05)$. Equal proportions of the all-plant extracts were mixed with the artificial feeds at concentrations of $100,200,400$, and $800 \mathrm{mg} \mathrm{kg}^{-1}$ of diet and fed to grouper juveniles of $20 \pm 2 \mathrm{~g}$ average weight for a period of 60 days. Every 20 days, fish juveniles were challenged with $V$. harveyi and the immune response was studied. The herbal diets significantly $(P<0.05)$ increased the survival, growth, and immune responses compared to the control group. The herbal diets were significantly improved $(P<0.01)$ in immune parameters such as phagocytic activity and albumin-globulin $(A-G)$ ratio. Among the different concentrations of the herbals in the diet, the $400 \mathrm{mg} \mathrm{kg}^{-1}$ diet was the most effective in the experiment.
\end{abstract}

Keywords Antibacterial · Herbals - Epinephelus tauvina - Immunostimulants · Vibrio harveyi

\section{Introduction}

Groupers are commercially important marine food fish in several countries, especially in south-east and middle-east Asia. Since market demand for groupers is larger than supply from captures and fisheries and considering the fast-growing economic importance of

\footnotetext{
S. M. J. Punitha - M. M. Babu - V. Sivaram - V. S. Shankar - S. A. Dhas · G. Immanuel ·

T. Citarasu $(\bowtie)$

Centre for Marine Science and Technology, Manonmaniam Sundaranar University, Rajakkamangalam,

Kanyakumari, Tamilnadu 629502, India

e-mail: citarasu@gmail.com

T. C. Mahesh

P.G. Department of Zoology, Vivekananda College, Agasteeswaram, Kanyakumari,

Tamilnadu 629701, India
} 
grouper culture in recent years, many countries are nowadays concentrating on developing commercial grouper farming technology (Al-Thobaity and James 1996). Many commercial grouper fish farms depend mainly on juveniles collected from the wild due to hatchery constraints and poor larval survival, which limits commercial expansion of grouper farming in south-east Asian countries (Chen 1979; Tseng 1983).

In the early 1990s grouper production in Hong Kong was about 3,000 t/year. In the last few years, production has dropped to 1,000 t/year due to environmental problems such as poor water conditions leading to stresses and disease outbreaks (Sadovy 2000). A number of diseases for groupers have been reported and the main causative agents are the typical group of parasitic organisms, bacteria, and viruses. Pathogenic bacteria cause severe losses in hatchery and grow-out culture systems which are usually related to poor management and water quality. Fish are easily stressed by improper handling and can become infected with Flexibacteria, leading to skin damage and tail rot. Gram-negative bacteria, especially Vibrio parahaemolyticus and V. alginolyticus, cause haemorrhagic septicaemia in grouper in nursery and grow-out cage systems. The Gram-positive bacteria Streptococcus sp. also causes systemic infection in grouper. Affected fish exhibit signs of weakness, abnormal swimming, and occasionally corneal hemorrhage (Danayadol et al. 1995). A range of bacterial diseases has also been reported, including Vibrio spp., Pseudomonas sp., Pasteurella piscicida and Flexibacter sp. Bacteriosis caused by Pseudomonas sp. among E. tauvina cultured in Malaysia was first reported by Nash et al. (1987), where all age groups were affected during an outbreak in November/December to February/March in 1982-1986. Mortalities ranged from $20 \%$ to $60 \%$. Affected fish showed extensive haemorrhagic erosions and ulcerations of the skin, fins, and tail. Also V. harveyi (CMB57) and other microbiota such as Streptococcus, Pseudomonas, Cornybacterium, Staphylococcus, and Proteus spp. were isolated from the body fluid and blood of the infected Grouper E. tauvina. Among the isolated microbiota from the body fluid and blood, $V$. harveyi dominated the other bacteria found in the body fluid (Sheeja et al. 2003; Sivaram et al. 2004).

Chemotherapy is widely used to control infectious parasitic, bacterial, and fungal diseases. It has been used for the control of parasitic and bacterial diseases of grouper. However, experience demonstrates that there are problems in chemical treatment of fish diseases; in some cases the treatments can be harmful because of associated stress. In Singapore, Chong and Chao (1986) reported some cases of drug overdose leading to fish death and other detrimental side-effects. Formalin overdose results in severe gill damage. Ulcerative dermatitis develops with repeated treatment with nitrofurazone, leading to fish death. Application of chemotherapeutants has created problems with toxicity, resistance, residues, and possibly some public health and environmental consequences. Their efficacy under certain aquatic conditions (open-water systems) remains questionable, and they can be costly. The use of chemicals in treating health problems has also been complicated by the misleading advice provided to the farmers by feed and chemical companies regarding the use of antibiotics and other therapeutic drugs.

Some chemotherapeutic agents of plant origin that have been isolated promise to deal with drug-resistant bacteria (Richard and Anthony 1983). Compounds such as volatile oils, tannins, phenolic compounds, saponins, alkaloids polysaccharides, and polypeptides were shown to be effective alternatives to antibiotics. The screening of plant extracts and natural products for antimicrobial activity has shown that higher plants represent a potential source of new anti-infective agents (Press 1996) as well as serve in drug discovery from natural products for primary lead compounds (Lawrence 1999). Traditional antibacterial therapy is going through a crisis due to the rapidly increasing development of resistance to existing agents. Such resistance has an impact on all areas of chemotherapy. Plant-derived 
phytomedicines have great promise in the treatment of infectious diseases. Plant-based antimicrobials represent a vast untapped source for medicines and have enormous therapeutic potential. They are effective in the treatment of infectious diseases while simultaneously mitigating many of the side-effects that are often associated with synthetic antimicrobials. Herbal products promise a cheaper source for therapeutics, greater accuracy than chemotherapeutic agents, and a viable solution for all problems which grouper culture faces today.

Several antimicrobial, antistress, immunostimulant, growth-promoting plant products significantly influenced the fish/shrimp larviculture (Citarasu et al. 1998, 2002, 2003a, 2003b). Sivaram et al. (2004) successfully controlled the Vibrio pathogen, and improved the immune system of grouper larviculture using herbal methanolic extracts. These findings suggest that phytochemicals could be an alternative to the chemotherapeutic molecules and safe to use in aquaculture. The present study focus on screening of selected antibacterial/immunostimulant herbals against the $V$. harveyi bacterial pathogen isolated from infected grouper and apply the products to grouper larviculture.

\section{Materials and methods}

Herbals

Five herbs with antimicrobial/immunostimulant characteristics were selected following Nadkarni (1995). The detailed descriptions are given in the Table 1.

Source of the bacterial culture

$V$. harveyi was isolated from the ulceration (wounds) of the infected Grouper, E. tauvina. Triplicate samples were aseptically blended with alkaline peptone water (Hi media) with $3 \% \mathrm{NaCl}$ and incubated at $37^{\circ} \mathrm{C}$ overnight for enrichment. The culture was plated on thiosulfate citrate bile salt sucrose (TCBS) agar (HIMEDIA, India). Further it was identified by morphological and biochemical conformations (Farmer and Hickman-Brenner 1992) as well as based on the characteristics described in Bergey's Manual of systematic bacteriology (Holt et al. 1994). The isolates were oxidase positive, sensitive to vibriostatic agents, grown in nutrient broth (HIMEDIA, India) with $3 \%$ and $6 \% \mathrm{NaCl}$ and TCBS agar. Serological tests were also done with standard anti- $V$. harveyi sera for species confirmation (Table 2). The pure cultures were stored in TCBS slants at $4^{\circ} \mathrm{C}$ for further experiments.

Extraction and screening of the herbals against $V$. harveyi using different solvents

Dried herbal powders were soaked in various solvents such as acetone, benzene, butanol, and petroleum ether individually for $48 \mathrm{~h}$ (Eloff 1998) in equal ratio (1:1). The slurry was then filtered, washed to remove nonsoluble fractions, and the filtrate was centrifuged $(20,000 \mathrm{~g}$ for $30 \mathrm{~min})$ for clarification. The clarified extracts were condensed at $35^{\circ} \mathrm{C}$ until the solvent residue had evaporated. Each $500 \mu \mathrm{g}$ of condensate was impregnated in 5-mmdiameter sterile paper discs (Himedia, India) and screened against $V$. harveyi through replicates of the disc diffusion test as described by Bauer et al. (1966). Dried antimicrobial discs with impregnated herbal extracts were carefully dispensed with uniform distances 


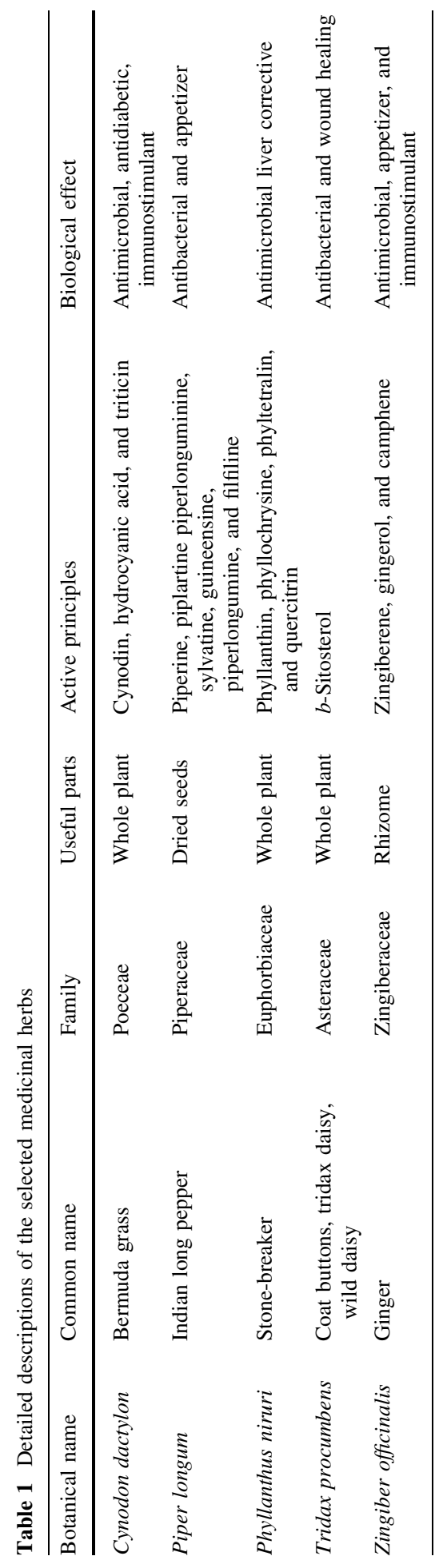


Table 2 Morphological and biochemical characteristics of the pathogen $V$. harveyi isolated from the Grouper $E$. tauvina

${ }^{a}$ Used as sole carbon source TSA Tryptic soy Agar

\begin{tabular}{|c|c|}
\hline Characters & Reactions \\
\hline Morphology & Curved rods \\
\hline Gram's stain & - \\
\hline Motility & + \\
\hline Swarming & - \\
\hline Swarming on TSA $(+2 \% \mathrm{NaCl})$ & - \\
\hline Growth in $6 \% \mathrm{NaCl}$ & + \\
\hline Growth in $12 \% \mathrm{NaCl}$ & - \\
\hline Oxidase (Kovacs) & + \\
\hline Indole production & + \\
\hline Voges-Proskauer test & - \\
\hline D-glucose acid & + \\
\hline Arginine dihydrolase (2nd and 7th day) & - \\
\hline Adonitol fermentation & - \\
\hline D-Xylose fermentation & - \\
\hline Erythritol fermentation & - \\
\hline Luminescence & Variable \\
\hline Cytochrome oxidase & + \\
\hline Nitrate reduction & + \\
\hline O/129 sensitivity & + \\
\hline Thornley's arginine dihydrolase & - \\
\hline Lysine decarboxylase & + \\
\hline Ornithine decarboxylase & + \\
\hline Voges-Proskauer reaction & - \\
\hline L-Arabinose ${ }^{\mathrm{a}}$ & - \\
\hline M-Inositol ${ }^{\mathrm{a}}$ & - \\
\hline D-Arabinose ${ }^{\mathrm{a}}$ & + \\
\hline Sucrose $^{\mathrm{a}}$ & Variable \\
\hline
\end{tabular}

over Muller Hinton agar surface and correct implantation was assured by applying gentle pressure over the disc. Control tests were carried out using sterile discs without impregnation of the herbal extracts. All plates were kept at $35^{\circ} \mathrm{C}$ for $24 \mathrm{~h}$ incubation. After the incubation time, plates were studied for inhibitory zone formation of antimicrobial extracts on microbial lawns in agar surface.

\section{Experimental culture}

Healthy Grouper E. tauvina juveniles weighing approximately $20 \pm 2$ g were caught from the Gulf of Mannar, India. They were acclimatized and kept in quarantine tanks for the period of 15 days to assess their disease-free health status. During this time, they were fed commercial feeds. After acclimatizing, five triplicated $(5 \times 3=15)$ experimental groups were stocked, having an average body weight of $22 \pm 1 \mathrm{~g}$ in 5001 capacity, flow-through aquaria with a water flow rate of $11 / \mathrm{min}$. The water quality parameters were maintained constantly (salinity $30 \pm 0.5 \mathrm{ppt}$, temperature $28 \pm 1.5^{\circ} \mathrm{C}$, DO $>6.0 \mathrm{mg} / \mathrm{l}$, ammonianitrogen $<0.22 \mathrm{mg} / \mathrm{l})$. 
Feed preparation and feeding

An equal proportion of all five petroleum ether herbal extracts was incorporated into five experimental diets, containing 0 (control), 100, 200, 400, or $800 \mathrm{mg} / \mathrm{kg}$ of the extract mixture. Diets were prepared following the basal ratio of Boonyaratpalin (1993). The basal diet contained $45.1 \%$ protein, $7.2 \%$ lipid, $14.6 \%$ ash, $7.1 \%$ moisture, and $3 \%$ fibre. To prepare the feeds, ingredients were mixed thoroughly and $4 \%$ gelatin solution containing the active principles at the appropriate concentration was added along with the oil ingredients. Sufficient water was added and the $\mathrm{pH}$ was adjusted to $7 \pm 0.1$. The mixture was then cold extruded, cut into pellets, air dried, and stored at room temperature.

Fish were fed with $5 \%$ of their body weight, every day until the end of experiment (60 days). The standard growth rate (SGR) was calculated by using the formula:

$$
\operatorname{SGR}(\%)=\frac{\left(\ln W_{2}-\ln W_{1}\right)}{t_{2}-t_{1}} \times 100,
$$

where, $\ln$ is the logarithm function, $W_{2}$ is the final weight at time $t_{2}$, and $W_{1}$ is the initial weight at time $t_{1}$.

\section{Challenge experiment}

On the 20th, 40th and 60th day of feeding experiment, five fishes were challenged with a lethal dose of $V$. harveyi $\left(1 \times 10^{8}\right)$ (isolated from the infected E. tauvina, cultured and maintained using Tryptic soy broth and agar with $2 \% \mathrm{NaCl}$ W/V) intramuscularly, transferred to a 2501 aquaria, and observed for 5 days for pathological signs.

\section{Immunological parameters}

Every 20 days, $24 \mathrm{~h}$ after final feeding, five randomly chosen fish from each experiment and control group, were taken and anaesthetized with $50 \mathrm{mg} \mathrm{MS}-222 / \mathrm{dm}^{3}$ of water, and used for blood collection. Blood was collected from caudal vein, with $1 \mathrm{ml}$ plastic syringe rinsed with anticoagulant, and a part of the blood was transferred immediately, added to an equal volume of $10 \%$ tri sodium citrate, and stored at $4{ }^{\circ} \mathrm{C}$. The remaining blood was kept at room temperature for $1 \mathrm{~h}$ without anticoagulant to collect the serum and stored at $40^{\circ} \mathrm{C}$.

For phagocytosis assay, $10^{7}$ cells of formalin-killed $V$. harveyi were added to $0.1 \mathrm{ml}$ of pooled blood samples from two fishes in a sterile microplate and incubated for $30 \mathrm{~min}$ at $25^{\circ} \mathrm{C}$ after thorough mixing in the well. After incubation, the blood-bacteria suspension was mixed gently and $50 \mu \mathrm{L}$ of this suspension was smeared on three glass slides. After air drying, the smears were fixed in $95 \%$ ethanol, redried, and stained with May-Grunwald's Giemsa. The phagocytic cells and phagocytosed bacteria were counted (Park and Jeong 1996).

For the study of serum bactericidal activity, two fishes from each groups were injected with $0.1 \mathrm{ml} / \mathrm{kg}$ body weight with live $V$. harveyi suspension $\left(10^{5}\right.$ cells $\left./ \mathrm{ml}\right)$ and blood samples were collected 10 and 90 min after injection. One hundred microliters of blood was serially diluted and plated in the TCBS medium (Hi media, India). The albuminglobulin ratio $(\mathrm{A}-\mathrm{G})$ of the sera was calculated following the method of Sahoo et al. (1999). The serum samples were analyzed for total protein following the dye-binding 
method of Bradford (1976), using bovine serum albumin as standard, for albumin by the bromocresol green method, and for globulin by subtracting the albumin value from the total protein value. Finally, the albumin-globulin ratio $(A-G)$ was calculated.

\section{Statistics}

Data were analyzed using one-way analysis of variance (ANOVA) following Zar (1974), to discover the significant difference at the 5\% $(P<0.05)$ level.

\section{Results}

Screening of herbal against the dominant pathogen $V$. harveyi

Among the different solvent extracts, those of benzene and petroleum ether (Fig. 1) effectively controlled the pathogen $V$. harveyi isolated from the infected grouper. The zones of inhibitions for benzene were 12.83 and $14.16 \mathrm{~mm}$ of $C$. dactylon and P. longum, respectively. Also the petroleum ether extracts exhibited 13, 12, and $14.5 \mathrm{~mm}$ inhibition zones for $C$. dactylon, $P$. niruri, and T. procumbens, respectively.

\section{Bacterial challenge}

In all challenges of grouper juveniles (20th, 40th, and 60th day) by $V$. harveyi, the control group had the highest and fastest mortality. Survival was significantly increased $(P<0.05)$ for the groups fed diets incorporating the herbal immunostimulant. Only a slight variation in survival was observed after the 20th day challenge among the different concentrations of

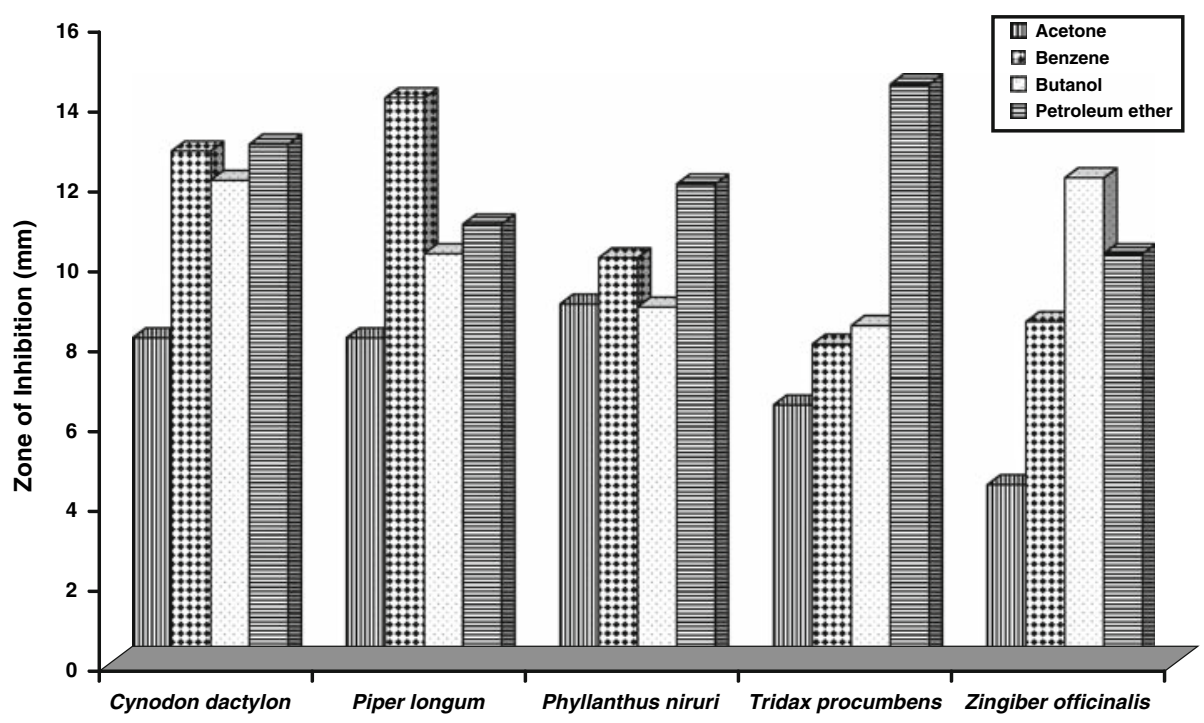

Fig. 1 Screening the antibacterial activity of different organic solvent extracts of the selected herbs on the dominant pathogen $V$. harveyi isolated from infected Grouper E. tauvina 
herbal diets. The maximum survival of $32.66 \%$ was observed for the $400 \mathrm{mg} / \mathrm{kg}$ diet. Surprisingly, on the 60th day after challenge, the herbal diets yielded very good results and attained survival rates of $78.33 \%, 84.66 \%, 92.0 \%$, and $93.33 \%$ for the $100,200,400$, and $800 \mathrm{mg} / \mathrm{kg}$ diets, respectively (Fig. 2).

\section{Growth performance}

Percentage standard weight gain (SGR) was calculated from the difference between the final and initial weight of the each fish group (Table 3). The SGR of the control group was $0.70 \%$. This was significantly increased $(P<0.05)$ to $1.22,1.37,1.47$, and $1.47 \%$ in the $100,200,400$, and $800 \mathrm{mg} / \mathrm{kg}$ diets, respectively. The gain was increased a fold from the control group to the 400 and $800 \mathrm{mg} / \mathrm{kg}$ diets, respectively.

\section{Immunological parameters}

The percentage phagocytic activity showed a significant variance $(P<0.01)$ between the control group and the groups fed the herbal diets in different days of challenging. Only

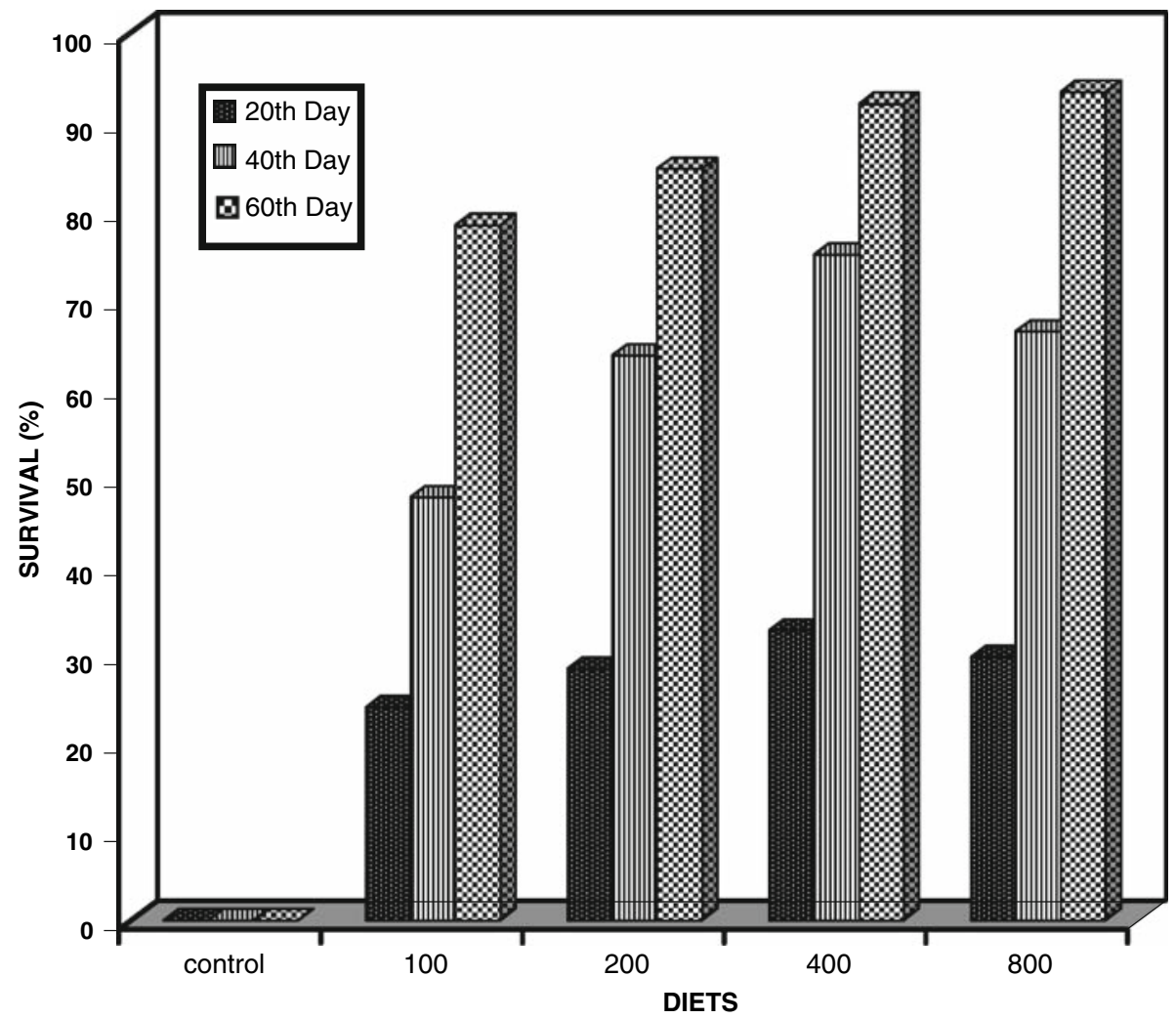

Fig. 2 Percentage survival after challenge with $V$. harveyi for the Grouper E. tauvina juveniles fed diets incorporating the herbal immunostimulant 
Table 3 Growth characteristics of Grouper E. tauvina juveniles fed diets containing different concentrations of the herbal immunostimulant for the period of 60 days

\begin{tabular}{lccl}
\hline Diet $(\mathrm{mg} / \mathrm{kg})$ & Initial wt. $(\mathrm{g})$ & Final wt. $(\mathrm{g})$ & SGR $(\%)$ \\
\hline Control & $21.9 \pm 0.36$ & $33.46 \pm 0.61$ & $0.70^{\mathrm{a}} \pm 0.00$ \\
100 & $21.96 \pm 0.50$ & $45.76 \pm 0.28$ & $1.22^{\mathrm{b}} \pm 0.071$ \\
200 & $21.76 \pm 0.25$ & $49.8 \pm 49.8$ & $1.37^{\mathrm{c}} \pm 0.078$ \\
400 & $22.22 \pm 0.25$ & $53.83 \pm 1.83$ & $1.47^{\mathrm{d}} \pm 0.05$ \\
800 & $21.66 \pm 0.28$ & $52.43 \pm 0.76$ & $1.47^{\mathrm{d}} \pm 0.001$ \\
\hline
\end{tabular}

Values with the same lower-case superscript do not differ significantly from each other $(P<0.05)$ based on one-way ANOVA

around $30 \%$ of the $V$. harveyi is phagocytosed in the control group. The herbals extracts increased the ingestion of the bacteria significantly $(P<0.05)$. The highest value of $77 \%$ was observed for the $400 \mathrm{mg} / \mathrm{kg}$ diet on the 60th day after challenge (Table 4).

The serum bactericidal activity and albumin-globulin $(A-G)$ ratio are tabulated in Table 5. Compared to the control group, a significant $(P<0.01)$ increase in the serum bactericidal activity was observed for the diets incorporating herbal extract. For the $400 \mathrm{mg} / \mathrm{kg}$ diet, the increase was nearly $70 \%$. Also, significantly $(P<0.01)$ increased A-G ratios of 4.13, 3.52, and 3.36 were observed in the groups fed 400, 800, and $200 \mathrm{mg} / \mathrm{kg}$ herbal diets, respectively. The control group attained a value of only 1.65.

\section{Discussion}

In aquaculture, chemotherapeutic agents such as commercial antibiotics and disinfectants are commonly employed for disease management, although this is not advisable due to cost effectiveness, environmental hazards, and the antibiotic resistance developed by many pathogens (Kruse and Soram 1994). To overcome this present situation, herbal medicine can be used as an effective antimicrobial drug. These are the ancient Indian systems of health care and longevity (Citarasu et al. 2002), but are still rejected by the scientific community due to a lack of standardization (Ponni 2002). In the present study, four different extracts of the five herbs effectively controlled the pathogen Vibrio harveyi. This was supported by Jinish (2002), who extracted the plants Terminalia bellerica, Ocimum sanctum, Daemia extensa, Andrographis paniculata, Solanum suratense,

Table 4 Phagocytic activity (\%) of Grouper E. tauvina juveniles fed diets containing the herbal immunostimulant for the period of 60 days

\begin{tabular}{lccc}
\hline Diet $(\mathrm{mg} / \mathrm{kg})$ & \multicolumn{2}{l}{ Phagocytic activity $(\%)$} & 60 th Day \\
\cline { 2 - 4 } & 20th Day & 40th Day & $30.33^{\mathrm{a}} \pm 1.52$ \\
\hline Control & $26.16^{\mathrm{a}} \pm 1.04$ & $30.50^{\mathrm{a}} \pm 1.80$ & $51.00^{\mathrm{b}} \pm 2.00$ \\
100 & $43.66^{\mathrm{b}} \pm 1.52$ & $48.50^{\mathrm{b}} \pm 2.08$ & $65.66^{\mathrm{c}} \pm 3.05$ \\
200 & $56.33^{\mathrm{c}} \pm 1.52$ & $62.16^{\mathrm{c}} \pm 1.04$ & $77.0^{\mathrm{d}} \pm 1.0$ \\
400 & $68.99^{\mathrm{d}} \pm 2.01$ & $73.5^{\mathrm{d}} \pm 1.5$ & $71.66^{\mathrm{d}} \pm 3.05$ \\
800 & $65.0^{\mathrm{d}} \pm 1.0$ & $71.33^{\mathrm{d}} \pm 2.08$ &
\end{tabular}

Values with the same lower-case superscript do not differ significantly from each other $(P<0.05)$ based on one-way ANOVA 
Table 5 Albumin-globulin ratio $(\mathrm{A}-\mathrm{G})$ and the serum bactericidal activity of Grouper E. tauvina juveniles fed diets incorporating herbal immunostimulant after the end of the experiment

\begin{tabular}{llc}
\hline Diet $(\mathrm{mg} / \mathrm{kg})$ & Albumin-globulin ratio $(\mathrm{A}-\mathrm{G})$ & Serum bactericidal activity \\
\hline Control & $1.64^{\mathrm{a}} \pm 0.02$ & $4.83^{\mathrm{a}} \pm 0.20$ \\
100 & $3.10^{\mathrm{b}} \pm 0.10$ & $8.53^{\mathrm{b}} \pm 0.13$ \\
200 & $3.35^{\mathrm{b}} \pm 0.04$ & $12.33^{\mathrm{c}} \pm 0.05$ \\
400 & $4.15^{\mathrm{c}} \pm 0.03$ & $15.44^{\mathrm{d}} \pm 0.14$ \\
800 & $3.54^{\mathrm{b}} \pm 0.04$ & $12.62^{\mathrm{c}} \pm 2.08$ \\
\hline
\end{tabular}

Values with the same lower-case superscript do not differ significantly from each other $(P<0.05)$ based on one-way ANOVA

Tinospora cardifolia, Withania somnifera, and Myristica fragrans and tested the extracts against the gut microbiota isolates from the Grouper E. tauvina, and found them to have strong antimicrobial activity. Navarro et al. (1996) showed that methanolic plant extracts from Eucalyptus globules, Punica granatum, Artemisia mozicana, and Bovvania arborea posses strong in vitro antibacterial activity against the Staphylococcus aureus, E. coli, Pseudomonas sp., and Candida sp. In the present study, C. dactylon and P. niruri extracted by petroleum ether exhibited good antibacterial activity. Also Jinish (2002) reported independently that the plant extracts have antimicrobial activity against fish pathogenic bacteria.

Interestingly, the fish juveniles fed the herbal immunostimulant diets had above $90 \%$ survival after the 60th day challenge and $41 \%$ higher weight than the fish fed the control diet. Itami et al. (1998) examined the potency of oral administration of peptidoglycan derived from Bifidobacterium thermophilum to kuruma shrimps through an artificial pellet diet. After 95 days, the shrimps were challenged by Vibrio penaeicidae. The survival and other immune parameters were significantly improved compared to the control group. Citarasu et al. (2002) developed an Artemia-enriched herbal diet for Penaeus monodon with the combination of five herbs, which significantly increased growth and survival during stress conditions. Also, feeding with W. somnifera, Ferula asafoetida, and Mucuna pruriens remarkably accelerated the spawning rate, fecundity, and larval quality in hatcheries of P. monodon (Babu and Marian 2001). Several herbal principles have been tested for their growth-promoting activity in aquatic animals (Citarasu et al. 2002; Jayaprakas and Eupharsia 1996).

Ecoactiva, a glucon-based immunostimulant preparation, was effective in Snapper Pagrus auratus; especially significant was the enhancement of macrophage superoxide anion production. In the present study, in the grouper juveniles fed the 400 and $800 \mathrm{mg} / \mathrm{g}$ diets, the haemocytes engulfed the pathogens (phagocytic activity) more than twice as much as in the control group. Also the herbal diets $(200,400$, and $800 \mathrm{mg} / \mathrm{g})$ significantly influenced the albumin-globulin ratio, and tripled the serum bactericidal activity. The presence of antimicrobials and immunomodulatory principles in our experimental herbals (Nadkarni 1995) stimulate the immune system. Sivaram et al. (2004) screened the methanolic extracts of ten antibacterial herbs against $V$. harveyi isolated from infected cultured greasy Grouper (E. tauvina) and mixed selected herbal extracts in the artificial diets and fed the juvenile groupers. Among the ten plants, Ocimum sanctum, Withania somnifera, and Myristica fragrans showed significant improvements in immune parameters such as phagocytic activity, serum bactericidal activity, albumin-globulin (A-G) ratio, and leucocrit value. 
Immunostimulant effects of the dietary intake of various medicinal plant extracts such as Viscum album, Urtica dioica, and Zingiber officinalis on rainbow trout (Oncorhynchus mykiss) were investigated by Dügenci et al. (2003). In this experiment, fish fed diets containing herbals improved the nonspecific defense mechanisms, including extracellular and intracellular respiratory burst activities, phagocytosis in blood leukocytes, total plasma protein level, specific growth rate (SGR), and condition factor (CF). It is well known that fish treated with immunostimulants show increased phagocytosis as well as respiratory burst activity (Sakai 1999; Blazer et al. 1989). Siwicki et al. (1990) reported that oral administration of levamisole increased the phagocytic index of phagocytic cells. Additionally, it was reported that feeding yeast products Candida utilis and Saccharomyces cerevisiae gave rise to enhanced phagocytic activity of blood leukocytes in rainbow trout. Albumin-globulin ratio is a measurable humoral component of the nonspecific defences. The reduction of $\mathrm{A}-\mathrm{G}$ in aflatoxin-treated glucan-fed fish might be due to increased total serum globulin level, with significance for the protective mechanisms of fish. Also the immunostimulants $\beta-1,3$ glucan and aflatoxin B1 (AFB1) improved the specific immunity against Aeromonas hydrophila challenge in Labeo rohita fish (Sahoo and Mukherjee 2001).

The different parameters of the present work revealed that these herbal immunostimulants are very effective against the $V$. harveyi infection in the juvenile grouper and further work should be done on the isolation and characterization of the active compounds from these herbals.

Acknowledgements One of the authors, Dr. T. Citarasu, gratefully acknowledges the Department of Science and Technology (DST), Ministry of Science and Technology, Govt. of India, for its financial support, in the form of a research grant (Young Scientist Fellowship—SR/FT/L-27/2005).

Open Access This article is distributed under the terms of the Creative Commons Attribution Noncommercial License which permits any noncommercial use, distribution, and reproduction in any medium, provided the original author(s) and source are credited.

\section{References}

Al-Thobaity S, James CM (1996) Developments in grouper cultures in Saudi Arabia. Infofish Int 1/96:22-29

Babu MM, Marian MP (2001) Developing bioencapsulated herbal products for maturation and quality larval production in Penaeus monodon (L.). In: Hendry C, Van Stappen G, Wille M, Sorgeloos P (eds) Larvi 2001. 3rd fish and Shell fish Larviculture symposium. Spec Publ Eur Aquac Soc 30:40-43

Bauer A, Kirby WMM, Sherris TC (1966) Antibiotics susceptibility testing by a single disc method. Am J Clin Pathol 45:493

Blazer VS, Ankey GT, Finco-Kent D (1989) Dietary influences on disease resistance in channel catfish. Dev Comp Immunol 13:43-48

Boonyaratpalin M (1993) Nutritional requirements of grouper Epinephelus. The Proceedings of Grouper Culture. National Institute of Coastal Aquaculture. Department of Fisheries, Thailand, pp 50-55

Bradford MM (1976) A rapid and sensitive method for the quantification of microgram quantities of protein utilizing the principle of protein-dye binding. Anal Biochem 72:248-254

Chen FY (1979) Progress and problems of net cage culture of grouper (Epinephelus tauvina) in Singapore. Proc Annu Meet World Maric Soc 10:260-271

Chong YG, Chao TM (1986) Common diseases in marine Fin fish. Primary Production Department, Republic of Singapore, $34 \mathrm{pp}$

Citarasu T, Babu MM, Marian MP (1998) Application of biomedicinal products for improving marine shrimp larval production. Aqua-Terr. Annual symposium. School of Biological sciences, M. K. University, Madurai, India

Citarasu T, Sekar RR, Babu MM, Marian MP (2002) Developing Artemia enriched herbal diet for producing quality larvae in Penaeus monodon. Asian Fish Sci 15:21-32 
Citarasu T, Venket Ramalingam K, Raja Jeya Sekar R, Micheal Babu M, Marian MP (2003a) Influence of the antibacterial herbs, Solanum trilobatum, Andrographis paniculata and Psoralea corylifolia on the survival, growth and bacterial load of Penaeus monodon post larvae. Aquac Int 11:583-595

Citarasu T, RajaJeyaSekar R, Venketramalingam K, Dhandapani PS, Marian MP (2003b) Effect of wood apple Aegle marmelos, Correa (Dicotyledons, Sapindales, Rutaceae) extract as an antibacterial agent on pathogens infecting prawn (Penaeus indicus) lariviculture. Indian J Mar Sci 32(2):156-161

Danayadol Y, Direkbusarakom S, Supamattaya K (1995) Viral nervous necrosis in brown spotted grouper, E. malabaricus, cultured in Thailand. In: Shariff M, Arthur JR, Subasinghe RP (eds) Diseases in Asian aquaculture II. Fish health section. Asian Fisheries Society, Manila, pp 227-233

Dügenci SK, Arda N, Candan K (2003) Some medicinal plants as immunostimulant for fish. J Ethnopharmacol 88:99-106

Eloff JN (1998) Which extractant should be used for the screening and isolation of antimicrobial components from plants? J Ethnopharmacol 60:1-8

Farmer JJ, Hickman-Brenner FW (1992) The genus Vibrio and Photobacterium. In: Balows A, Truper HG, Dworking M, Harder W, Schleifer KH (eds) The prokaryotes, 2nd edn. Springer Verlag, New York, pp 2952-3011

Holt JG, Krieg NR, Sneath PHA, Stanley JT, Williams ST (1994) Bergeys manual of determinative bacteriology, 9th edn. Williams \& Wilkins, Baltimore, p 559

Itami T, Asano M, Tokushige K, Kubono K, Nakagawa A, Takeno N, Nishimura H, Maeda M, Kondo M, Takahashi Y (1998) Enhancement of disease resistance of kuruma shrimp, Penaeus japonicus after oral administration of peptidoglycan derived from Bifidobacterium thermophilum. Aquaculture 164:277-288

Jayaprakas V, Eupharsia J (1996) Growth performance of Labeo rohita (Ham.) Livol (IHF-1000), an herbal product. Proc Indian Natl Sci Acad 63(2):1-10

Jinish LJG (2002) Ayurvedic phytotherapeutics against Vibrio infections in grouper, Epinephelus tauvina, M.Sc. Dissertation, M. S. University, Tirunelveli, Tamil Nadu, India

Kruse H, Soram H (1994) Tromster of multiple drug resistance plasmids between bacteria of diverse origins in natural environments. Appl Environ Microbiol 60(1):4015-4021

Lawrence RN (1999) Rediscovery natural product biodiversity. Drug Discov Today 4:449-451

Nadkarni KM (1995) Indian Materia Medica with Ayurvedic, Unani, Tibbi, Sidha, Allopathic, Homeopathi, Naturopathi and Home Remedies Appendices and indexes, vols I and II. Ram Pintograph, New Delhi, India

Nash G, Anderson IG, Shariff M, Shamsudin M (1987) Bacteriosis associated with epizootic in the giant sea perch, Lates calcarifer, and the estuarine grouper, Epinephelus tauvina, cage-cultured in Malaysia. Aquaculture 67:105-111

Navarro V, Villarreal LMA, Lozoya RGX (1996) Antimicrobial evaluation of some plants used in Mexican traditional medicine for the treatment of infections diseases. J Ethnopharmacol 53(3):143-147

Park KH, Jeong HD (1996) Enhanced resistance against Edwardsiella tarda infection in tilapia (Oreochromis niloticus) by administration of protein-bound polysaccharide. Aquaculture 143:135-143

Ponni A (2002) Ethanotherapeutics. An approach to study the antimicrobial evaluation of some siddha and ayurvedic medicines for the treatment of infectious disease. M. Sc. Dissertation, M. S. University, Tamil Nadu, India

Press JB (1996) Biodiversity. Exciting prospects for drug discovery and development melting report of the Monroe Wall Symposium. Chemtracts Org Chem 9:286-298

Richard EK, Anthony TT (1983) Plant and fungal toxins. Marcel Dekker, New York

Sadovy Y (2000) Regional survey for fry and fingerling supply and current practices for grouper mariculture. Evaluating current status and long term prospects for grouper mariculture in south east Asia. Final report to the collaborative APEC grouper research and development network, (FWG 01/99)

Sahoo PK, Mohanty J, Mukherjee SC (1999) The three imuunomodulators on haemotological parameters and immunity level in rohu (Labeo rohita) fingerlings. J Aquac Trop 14:127-135

Sahoo PK, Mukherjee SC (2001) Effect of dietary $\beta-1,3$ glucan on immune responses and disease resistance of healthy and aflatoxin B1-induced immunocompromised rohu (Labeo rohita Hamilton). Fish Shellfish Immunol 11:683-695

Sakai M (1999) Current research status of fish immunostimulants. Aquaculture 172:63-92

Sheeja L, Palavesam A, Immanuel G, Peter Marian M (2003) Phytotherapeutic antimicrobial characteristics of ayurvedic compounds against bacterial microflora isolated from infected grouper Epinephelus sp. In: Balakrishnan Nair N, Natarajamn P, Abdul Azis PK, Lipton P (eds) Proceedings of ICON-DMSF 2003. Department of Aquatic biology, University of Kerala, pp 149-150

Sivaram V, Babu MM, Citarasu T, Immanuel G, Murugadass S, Marian MP (2004) Growth and Immune response of juvenile greasy groupers (Epinephelus tauvina) fed with herbal antibacterial active principle supplemented diets against Vibrio harveyi infections. Aquaculture 237:9-20 
Siwicki AK, Anderson DP, Dixon OW (1990) In vitro immunositumulation of rainbow trout (O. mykiss) spleen cells with levamisole. Dev Comp Immunol 14:231-237

Tseng WY (1983) Prospects for commercial net cage culture of red grouper (Epinephelus akara T. and S) in Hong Kong. J World Maric Soc 14:650-660

Zar JH (1974) Biostatistical analysis, 6th edn. Prentice-Hall, New Jersey 